\title{
FEATURE Multifunctional Mississippi River leveed bottomlands and settling basins: Sny Island Levee Drainage District
}

\author{
Kenneth R. Olson, Mike Reed, and Lois Wright Morton
}

t was Red Rock, Saylorville, and Coralville lakes and the rivers that come out of Iowa that Mike Reed, superintendent of Sny Island Levee Drainage District in western Illinois, watched most closely as extreme weather events and flooding hit the Upper Mississippi River Basin in 2008, 2009, and 2010. The Sny Island Levee Drainage District located along the eastern bank of the Mississippi River (figure 1) controls runoff, holds water, and collects large volumes of sediment in basins using an elaborate maze of levees, basins, and diversion ditches. The Sny River channel, which runs parallel to the Mississippi River, is the central control structure that channels upland waters prior to pumping into the Mississippi River at three separate locations.

The oldest Drainage District in Illinois, officially established in 1880 shortly after the passage of the current Illinois Drainage Law in 1879, the Sny Island Levee Drainage District initially included approximately 44,000 ha $(110,000 \mathrm{ac})$ of floodplain bottomlands with 1,600 ha $(4,000 \mathrm{ac})$ of additional lands annexed later. The drainage district has operated for more than 130 years as a local government levee and drainage district and has been used by the Illinois Supreme Court as a model for the development of other drainage districts formed to enable public assessments for protecting agricultural land and valuable infrastructure from flooding. The US Army Corps of Engineers, which is responsible for the Mississippi River levees as we know them today, has been a key cooperator with the Sny Island Levee Drainage District. The circuit court sets the maximum assessment rate and gives the Sny Island Levee Drainage District the power to assess local farms and land own-

Kenneth R. Olson is professor of soil science in the College of Agricultural, Consumer, and Environmental Sciences, University of Illinois, Urbana, Illinois. Mike Reed is superintendent of The Sny Island Levee Drainage District, New Canton, Illinois. Lois Wright Morton is professor of sociology in the College of Agriculture and Life Sciences, lowa State University, Ames, lowa.

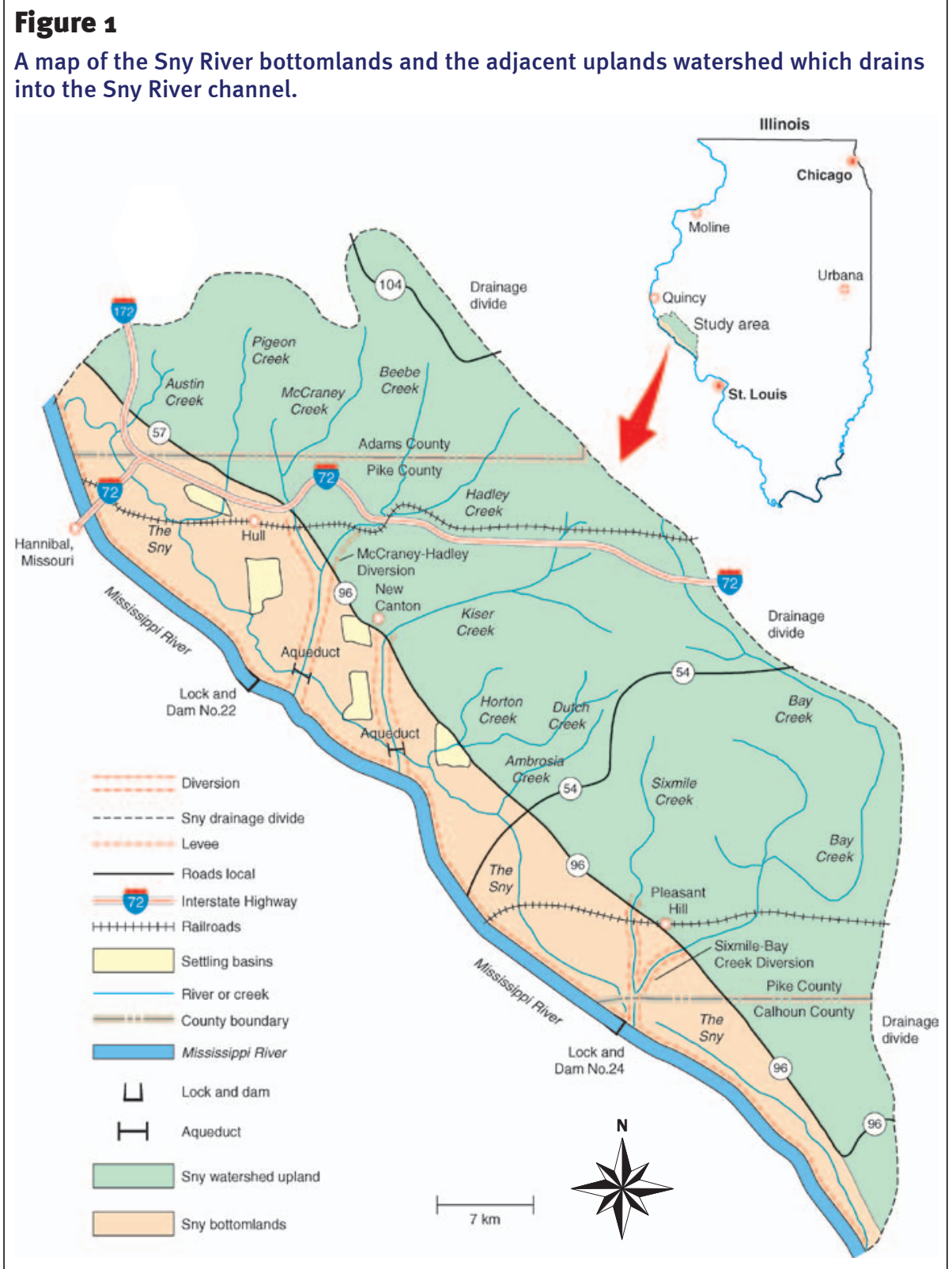

ers in the flood plain who receive a benefit of being protected from Mississippi River and interior flooding by the levee, pump stations, and gravity outlets.

The 2008 flooding in the Mississippi River valley did not break any of the levees of the Sny Island Levee Drainage District, and the 56,000 ha $(140,000 \mathrm{ac})$ of protected bottomlands did not flood (Olson 2009). This was not the case in 1993 Mississippi River basin flooding, when the northern most 16,000 ha $(40,000 \mathrm{ac})$ of the Sny Island Levee Drainage District protected bottomlands flooded. However, the District levees and diversion levees in the southern section protected the remaining 40,000 ha $(100,000 \mathrm{ac})$ of bottomlands from flooding. Assessment funds are used to maintain the levees and drainage systems along the Mississippi River. Parcel assessment is based on elevation and spatial location within the district. The average current assessment rate is $\$ 46$ $\mathrm{ha}^{-1}\left(\$ 18.50 \mathrm{ac}^{-1}\right)$. Three commissioners are 
elected in alternating years to the drainage district board as landowner representatives responsible for monitoring and managing the drainage district.

The total watershed area of the Sny Island Levee Drainage District, including the acreage in the District itself, is 176,348 ha $(440,871 \mathrm{ac})$ (figure 1). Of that amount, 100,864 ha $(252,160 \mathrm{ac})$ of watershed are diverted directly to the Mississippi River through Bay Creek (45.363 ha [113,408 ac]), Sixmile Creek (8,781 ha [21,952 ac]), McCraney Creek $(12,851$ ha $[32,128 \mathrm{ac}])$, Hadley Creek $(18,611$ ha [46,528 ac]), and Kiser Creek $(15,258$ ha $[38,144 \mathrm{ac}])$. The total watershed acres diverted into the sedimentation basins is 27,122 ha $(67,804$ ac). Of that amount, 7,373 ha $(18,432 \mathrm{ac})$ is diverted into Pigeon Creek Basin, 8,850 ha $(22,124 \mathrm{ac})$ into Dutch Horton Basin; 1,613 ha $(4,032 \mathrm{ac})$ into Austin Creek Basin, 2330 ha $(5,824$ ac) into Fall Creek Basin, 1664 ha $(4,160 \mathrm{ac})$ into Ambrosia Basin, 473 ha $(1,183$ ac) into Walnut Creek Basin, 184 ha (461 ac) into Pothast Basin, 681 ha $(1,703 \mathrm{ac})$ into Grubb Basin, 192 ha $(480 \mathrm{ac})$ into Shewhart Basin, 1,052 ha $(2,630 \mathrm{ac})$ into Brewster/Brown Basins, 1,360 ha $(3,400 \mathrm{ac})$ into Atlas/ Two Mile Basin, 1,200 ha (3,000 ac) into Howell Basin, and 150 ha (375 ac) into Johnson Basin.

\section{THE SNY RIVER CHANNEL}

More than 10,000 years ago, glacial flood waters in this Mississippi River valley flowed in multiple channels. As the water receded, it left behind a river bottom terrace called Sny Island and the Sny River, a branching channel that intercepts the many creeks that run out of the uplands (Gard 2002). In 2007, these nutrientrich bottomlands comprised more than a third of all Pike County, Illinois, acres in farmland (USDA NASS 2009). The eastern border of this Sny Island Drainage District is near state route 96 and route 57, which run parallel to the Mississippi River and at the base of the limestone bluffs, which separate the Mississippi bottomlands from the uplands (figure 1). The official eastern boundary of the Sny Island Levee Drainage District is the high water mark of the 1851 flood and includes several local stream floodplains to the east of route 96 that were later annexed to better control upland runoff and to provide a flooding benefit. The Pike County Soils report number 11, published in 1915 by the Department of Agronomy, University of Illinois (Hopkins et al. 1915), shows a Pike county levee extending all along the $80 \mathrm{~km}$ (54 mi) of the Mississippi River in Pike county (figure 1), and it is the western boundary of the Sny Island Levee Drainage District.

The Sny Island Levee Drainage District (figure 1) currently protects 5,377 tracts with a total of 45,600 ha $(114,000 \mathrm{ac})$ of floodplain bottomlands, which are mostly cultivated cropland (corn, soybeans, and some wheat) in the floodplain bottomlands. The bluffs are forested with little agricultural use, except for the valley bottoms adjacent to the creeks and streams. There are a number of small towns (including Kinderhook, New Canton, Rockport, Atlas, and Pleasant Hill) that are located on outwash from glaciers covered with alluvial fans created from past upland geological erosion events. The Sny River channel was reengineered and reconnected and still parallels the current Mississippi River. It is often only a few hundred meters (several hundred feet) to the east and was part of an old Mississippi River channel. The Sny River channel collects and stores water, sediment, and nutrients from local streams and watersheds before it is pumped or allowed to free flow into the Mississippi River in the upper three reaches of the district. The southernmost reach of the Sny River channel is now disconnected from the upper portion by the Sixmile-Bay Creek diversion levee. The lower reach of the Sny River channel still drains by gravity flow as well as pumping into the Mississippi River at river mile 269 in Calhoun County (figure 1). The Sny River channel name was not used on the 1915 Soil survey report since it was not continuous during dry periods. Instead, the maps showed a series of slough names such as Running Slough, Mud Slough, Salt Slough, and Burr Slough.

\section{SETTLING BASINS}

In the 1920s and 1930s, the Sny Island Levee Drainage District became concerned about the amount of sediment and nutrients that were entering and filling the Sny River channel and Mississippi River, as well as being deposited on Mississippi bottomlands as a result of local creek flooding events. Flooding of the Sny Island Levee Drainage District land continued to occur when local streams and creeks, such as Pigeon Creek, Hadley Creek, Kiser Creek, and Bay Creek, overflowed (figure 1). This resulted in flooded cropland and sediment being deposited on the agricultural bottomlands and in the Sny River channel. During some flooding events, the local runoff water was trapped behind (east side) the Mississippi River levees and resulted in crop loss even though the levees did not fail.

By the 1940s and 1950s, the Sny Island Levee Drainage District decided to create additional levees on local creeks and streams, as well as large settling basins, to protect agricultural land from local flooding and sediment deposition. Several hundred acres of these basins, including the 250 ha $(640 \mathrm{ac})$ McCraney basin located approximately $5 \mathrm{~km}$ (3 mi) south of Hull, Illinois, and the 250 ha (640 ac) Kiser Creek basin located $8 \mathrm{~km}$ (5 mi) west of New Canton, Illinois, were created (figure 1). Since the land where the sediment basins were to be placed was on private property, a lease arrangement was negotiated with the land owner. Landowners were paid for the use of their land to store sediment and nutrients during the years the sediment basin was active and the land could not be farmed. These sediment basins captured eroded soils carried by excess waters that were periodically diverted from adjacent streams, such as Hadley, McCraney, and Kiser creeks. As a result of the 1940s and 1950s cultivation practices (moldboard plowing) in the uplands of Adams, Pike, and Calhoun counties, these and other basins filled to 3 $\mathrm{m}(10 \mathrm{ft})$ depth in less than 20 years.

Once filled, the sediment-filled basins dried out and the depth of sediment shrunk. The embankments were graded to the level of the dried sediment (figure 2) and returned to the private land owners to be farmed. Currently, all of these earlier basins are being cultivated for corn and soybeans. The sediment-filled basins are still at least $2 \mathrm{~m}$ (7 ft) above the sur- 


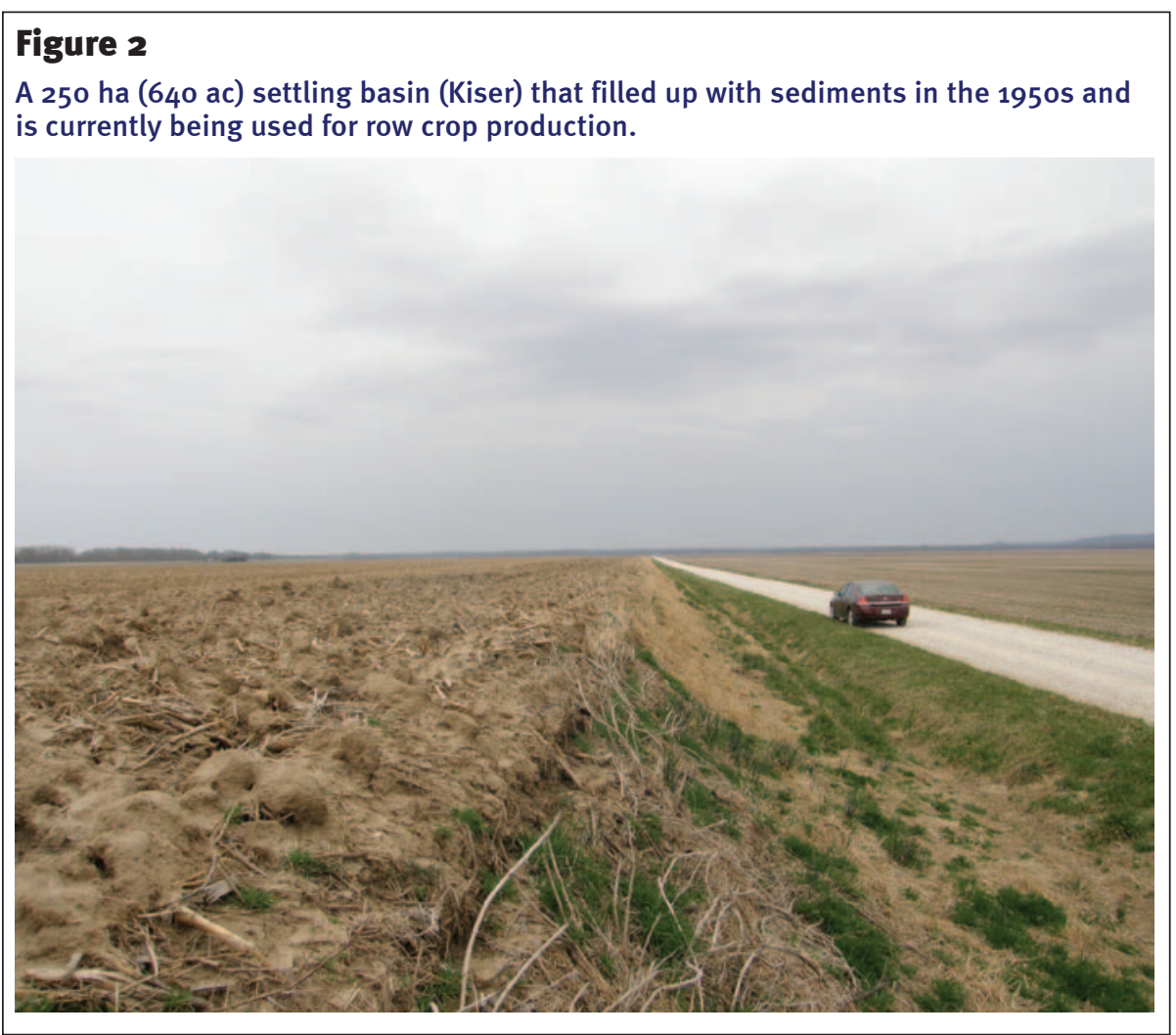

\section{Figure 3}

A 250 ha $(640 \mathrm{ac})$ settling basin (McCraney) that filled with sediments in the $1950 \mathrm{~s}$ and is 2 to $3 \mathrm{~m}$ above the bottomlands and 3 to $4 \mathrm{~m}$ above the current drainage ditch.

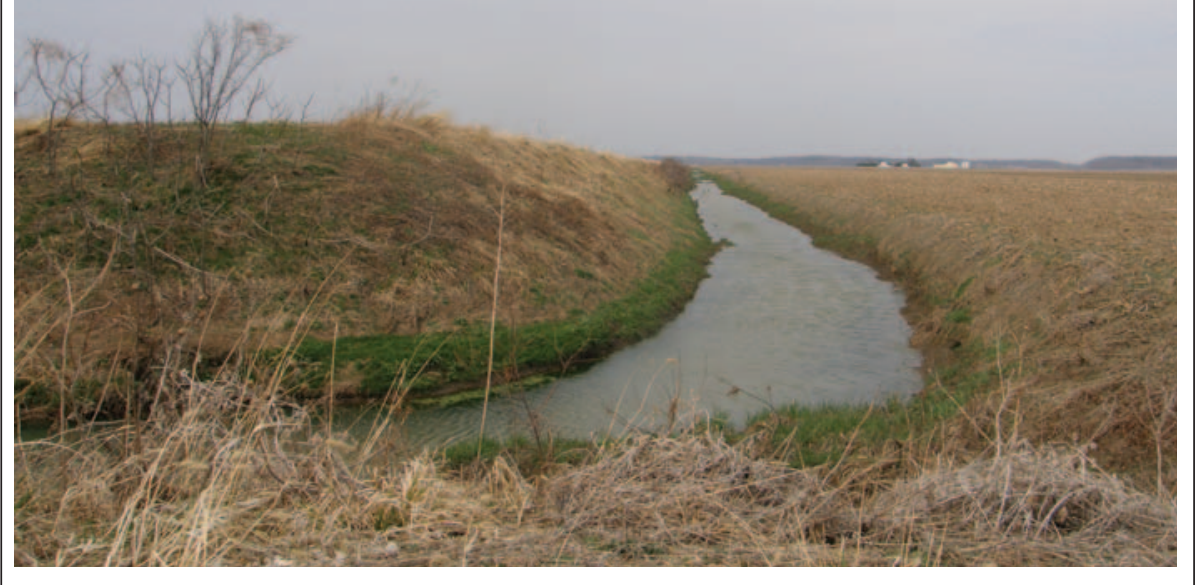

rounding fields on the bottomlands (figure 3). These sediment basins were mapped in the 1999 Pike county soil survey (Struben and Lilly 1999) as soil no.
University of Illinois (Olson and Lang 2000), assigned crop yield ratings and productivity index (PI) to these large inactive sediment-filled basins. The PIs of the soils at the sediment basin sites before construction and after filling were protected from Mississippi River flooding by a levee and do not have to be adjusted for Mississippi River flooding, but in some cases they are still adjusted for local stream flooding. The optimum PI for these manmade soils was 108 (on 147-point scale); these basins are now 2 or $3 \mathrm{~m}$ ( 7 to 10 $\mathrm{ft}$ ) higher than the original landscape with the PI no longer needing to be adjusted for local flooding. The original soils, such as Wakeland silt loam, Haymond silt loan, and Beaucoup silty clay loam, had PIs of between 128 and 132, but can be adjusted down to PIs of between 98 and 119 as a result of documented crop loss caused by local streams flooding. The PI adjustment varies by extent of crop loss within each county (Adams, Pike, or Calhoun).

By the late 1950s it became very apparent that the major east-west streams (Hadley Creek, McCraney Creek, Kiser Creek, Sixmile Creek, and Bay Creek) were transporting too much runoff water and sediment to the Sny River channel despite the construction of the individual 250 ha $(640 \mathrm{ac})$ settling basins on the major streams. A new approach to controlling and holding water was undertaken in the 1960s by the US Army Corps of Engineers with the assistance of the Sny Island Levee Drainage District. In addition to the creation of 1,040 ha $(2,600 \mathrm{ac})$ of new settling basins, such as the HortonDutch sediment basin (figure 4), three major diversions (levees on both sides of the major local creek or channel) were created (figure 1). These diversions routed the water from the largest watersheds in the uplands through the Sny Island Levee Drainage District bottomland area and discharged directly into the Mississippi River. These diversions became known as the Hadley-McCraney Diversion located in northern Pike county, the Kiser Creek Diversion located in central Pike county, and the Sixmile-Bay Creek Diversion located in southern Pike and northern Calhoun counties and include an upland watershed of approximately 100,864 ha 
$(252,160 \mathrm{ac})$. These diversions are approximately 10 to $18 \mathrm{~km}$ (6 to $12 \mathrm{mi}$ ) long, with 3 to $5 \mathrm{~m}$ (10 to $15 \mathrm{ft}$ ) high levees on both sides of the channel, and can be between 60 and $100 \mathrm{~m}$ (200 and $300 \mathrm{ft}$ ) wide with some cultivation, woodland, and wildlife in the diversion channels (figure 5). These diversions reduce the water, sediment, and nutrients going directly into the Sny River channel, while maintaining internal drainage control of the smaller watersheds in the uplands, and any sediment and nutrients from other drainage ditches in the Mississippi bottomlands within the Sny Island Levee Drainage District. The 1,200 ha $(3,000 \mathrm{ac})$ land in the diversions includes grassland, timberland, and cultivated land or is covered by water and becomes a significant wildlife habitat.

Two aqueducts (figure 1) under the Hadley-McCraney and Kiser Creek Diversions carry the water from the Sny River channel, which crosses almost perpendicular to both diversions (figure 6). The Sixmile-Bay Creek Diversion blocks the Sny River channel flow from the upper $80 \mathrm{~km}$ (54 mi) part of the channel watershed, including the 45,600 ha $(114,000 \mathrm{ac})$ of protected bottomlands in the Sny Island Levee Drainage District and the adjacent runoff from the bluffs and the smaller local creeks from the uplands (approximately $27,130$ ha $[67,824 \mathrm{ac}])$. The Sny River channel flow does not include the runoff water from the watersheds that drain into and through the three diversions. The Sixmile-Bay Creek Diversion levee directs the Sny River channel water to the pump station (near where the Sixmile-Bay Creek Diversion levee joins the Mississippi River levee [figure 7] and south of Lock and Dam no. 24). The Sny River channel water can be stored in the channel to allow sediment to settle, and eventually clear water is pumped or allowed to free flow into the Mississippi River, thereby reducing sediment and nutrient discharges. The last 7.5 $\mathrm{km}(5 \mathrm{mi})$ of the Sny River channel flows to southernmost pump station located at river mile 269 , where it can be pumped or allowed to free flow directly into the Mississippi River draining a small portion of the western upland watershed in Calhoun County.

\section{Figure 4}

Horton-Dutch creek settling basin filling up with water, sediment, and nutrients with the basin levee shown in the distance.

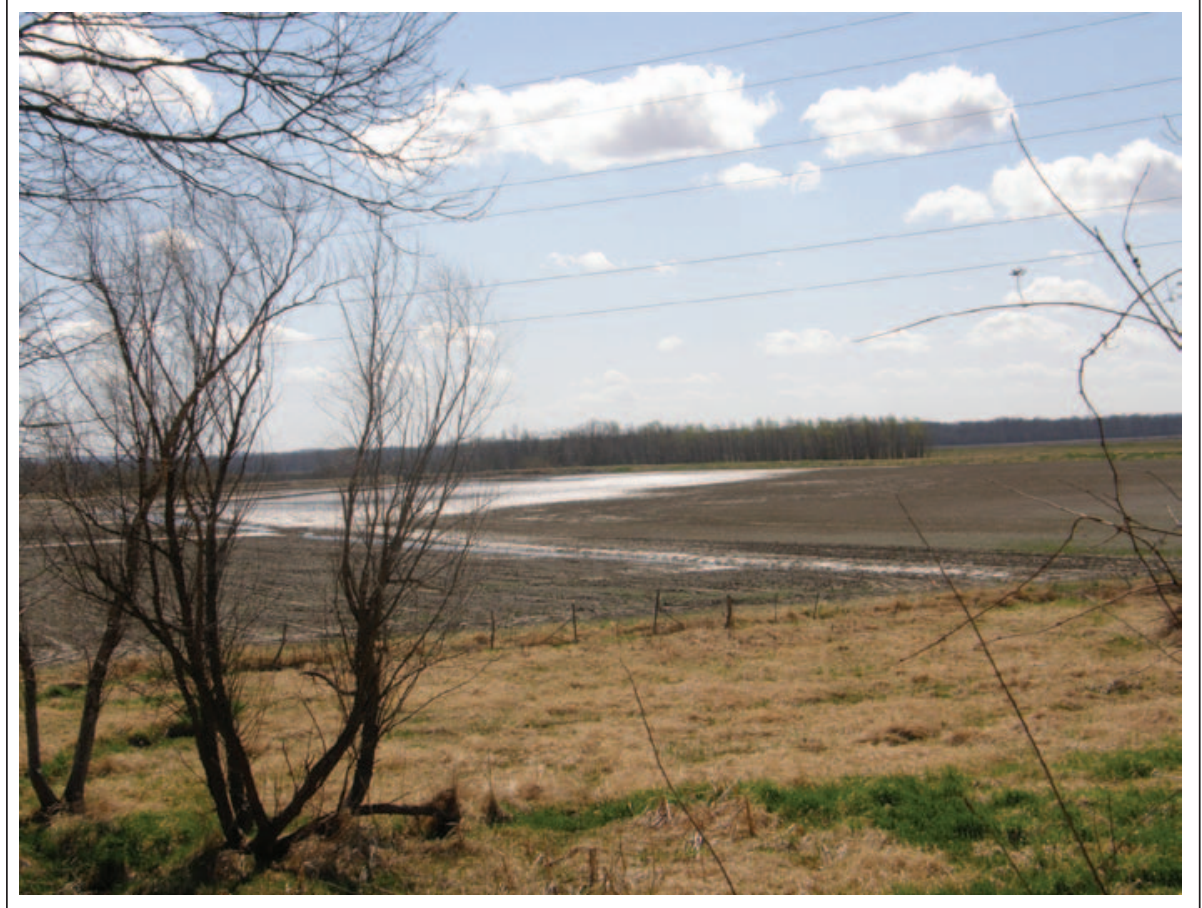

\section{Figure 5}

The wide Kiser diversion channel with timberland between the two levees just before it drains into the Mississippi River.

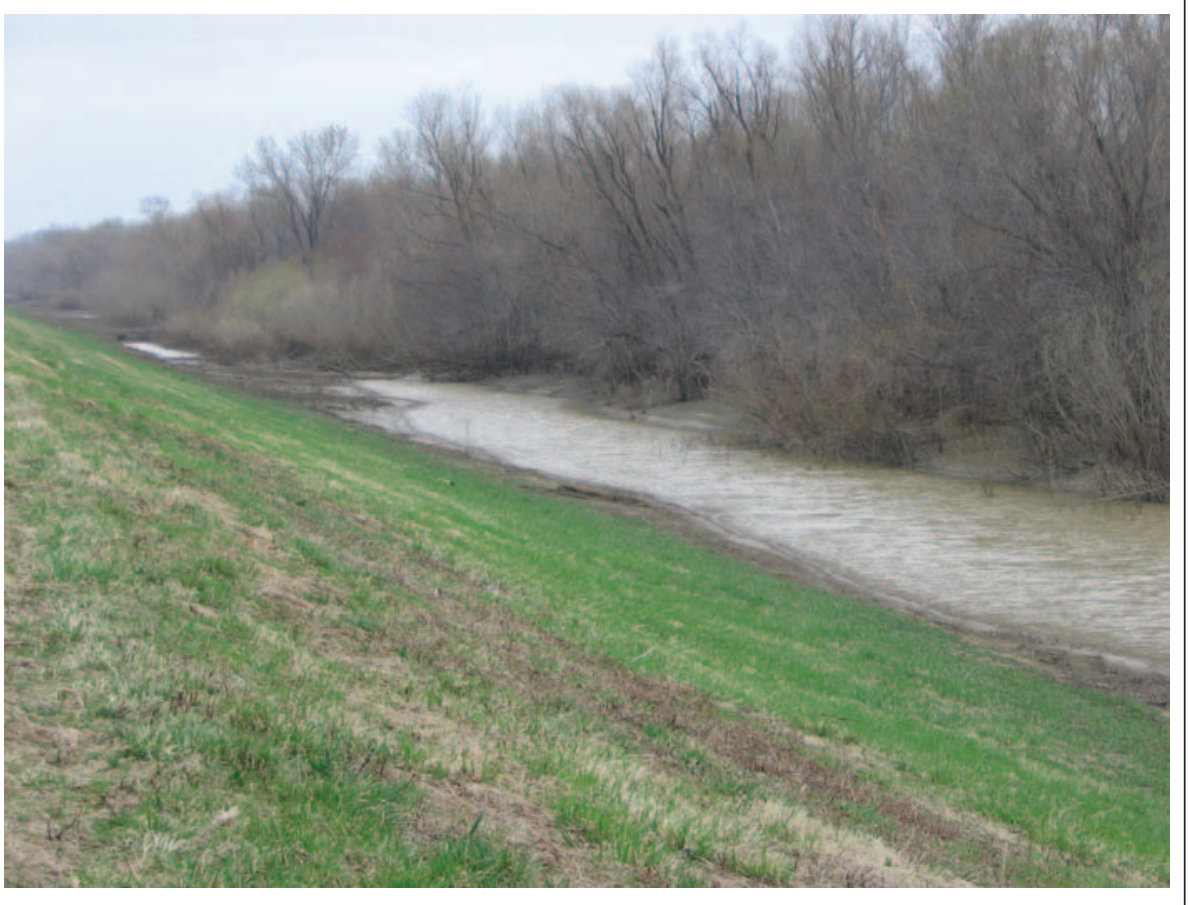

There are currently 15 sediment basins built since 1970, which cover 1,040 ha $(2,600 \mathrm{ac})$. Some sediment basins can be cultivated during dry periods and oth- ers remain ponded on at least one end and provide wildlife habitat and numerous hunting opportunities for the entire region. To the delight of the Sny Island 


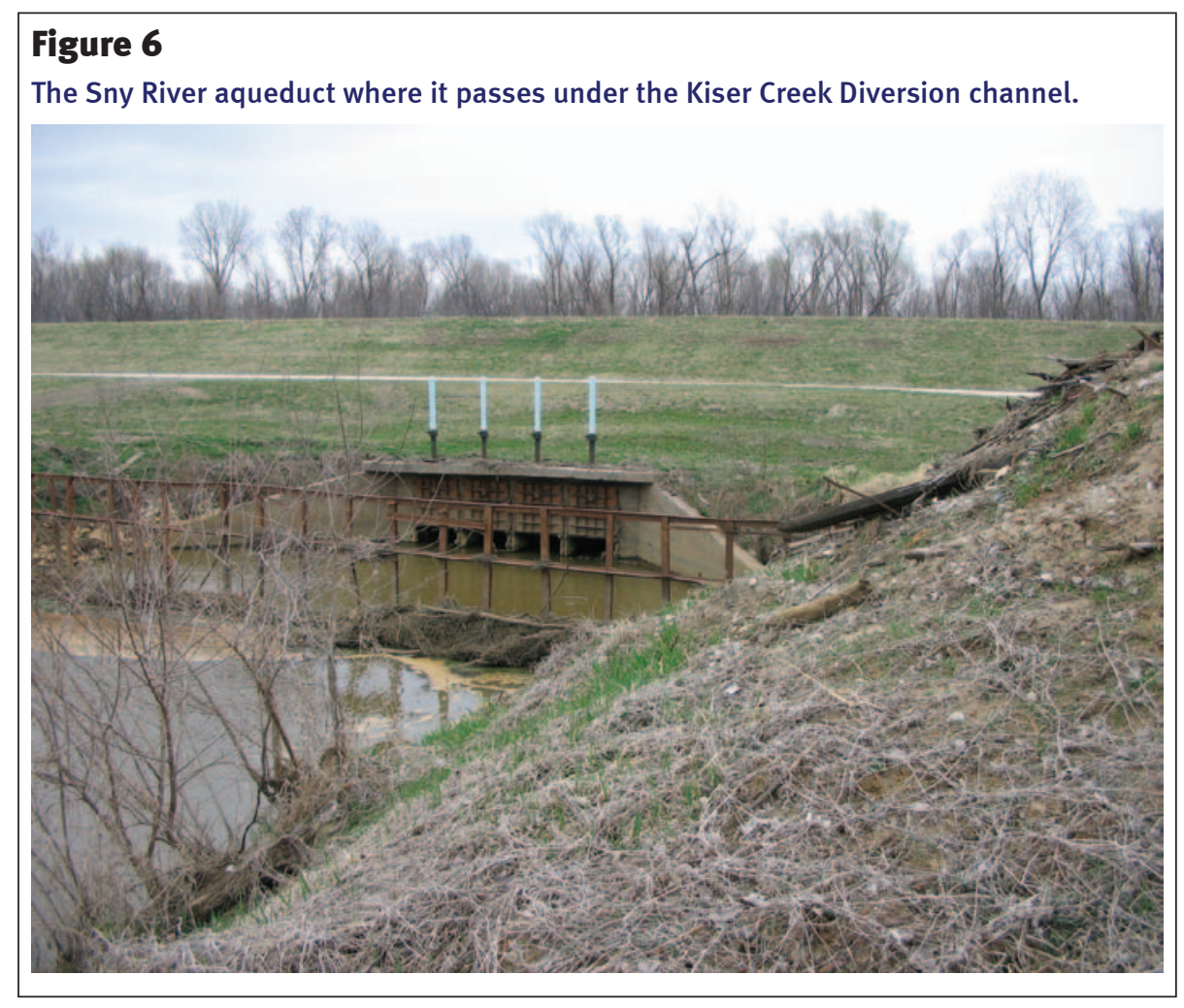

\section{Figure 7}

The merged Mississippi River and Kiser Creek Diversion levee which blocks the Sny River channel flow and water has to be pumped over the levee to Mississippi River.

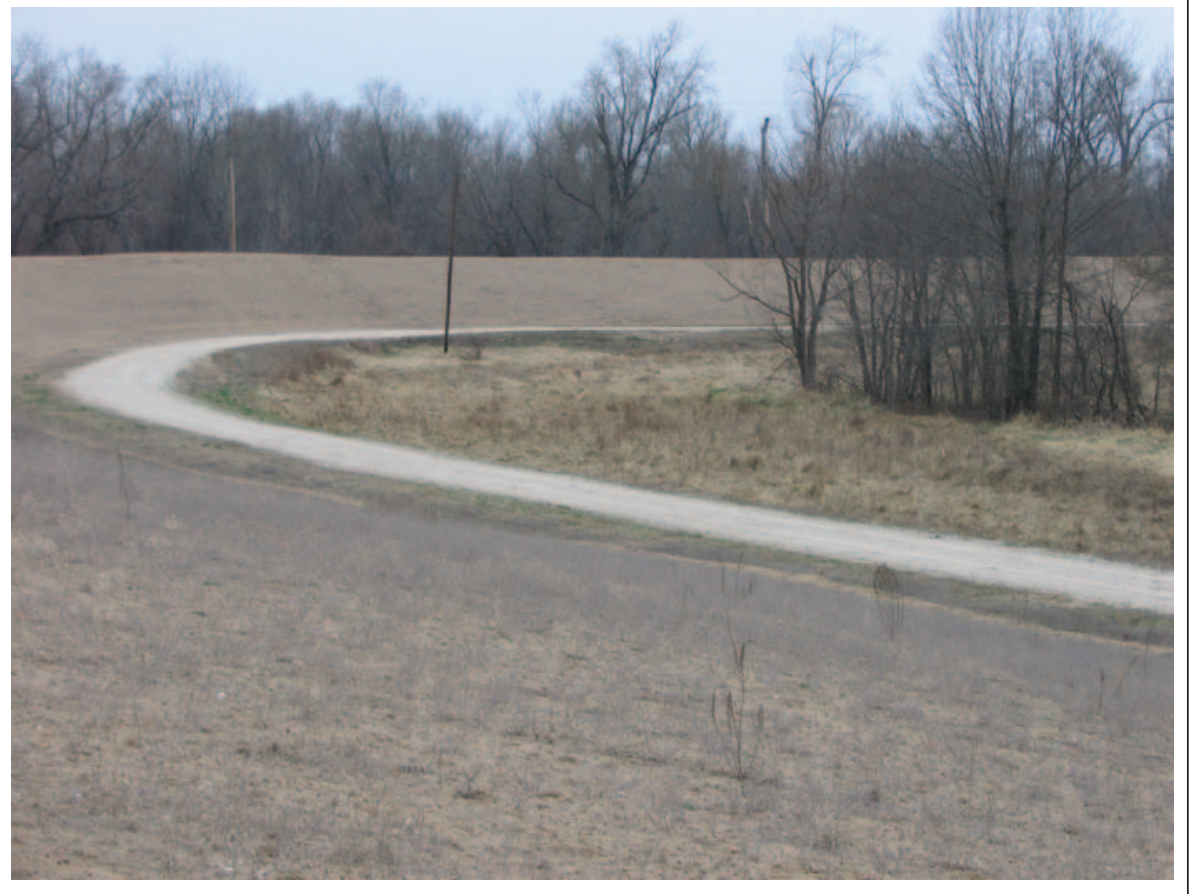

Levee Drainage District staff, the sediment basins, including Pigeon Creek basin (figure 8), no longer are filling up in less than 20 years. They have had a much longer active life (up to 3 times greater). There are and the other reason is changes in farming and cultivation practices on both the bottomlands and uplands to better manage soil erosion. In the 1970s, the primary tillage method changed from a moldboard plowing system to a chisel plow system. By the 1990s, many farmers replaced the chisel plow system with no-till (figure 9). This switch in farming systems was in part a result of the T by 2000 Illinois Erosion Control program that became law in 1983, as well as the Federal Food Security Act of 1985 (and later Farm Bills) that provided incentives and/or required farmers to reduce soil loss to $\mathrm{T}$ - tolerable levels to less than $11 \mathrm{mt} \mathrm{ha}^{-1}\left(5 \mathrm{t} \mathrm{ac}^{-1}\right)$ each year.

\section{OBSERVATIONS}

Strategically placed wetlands, settling basins, and levees are effective management practices for internal control of water and sediment, as well as nutrient filtering. Sny Island Levee Drainage District has been a pioneer in the development of ways to reduce local flooding and decrease the sediment and nutrient loads being discharged into the Mississippi River. Water is currently discharged at the rate of 0.6 $\mathrm{cm} \mathrm{day}^{-1}\left(0.25\right.$ in day $\left.{ }^{-1}\right)$. These measures allow the district to hold within the system as much as a month worth of water, thereby reducing the peak flow of water discharged into the Mississippi River. The series of local levees, diversions, water storage basins, and settling basins slow the discharge of water to the Mississippi River, allow time for nutrients and sediment to settle out, provide multiple land uses for the settling basins during their active life, and convert 1,040 ha $(2,600 \mathrm{ac})$ back into productive agricultural land (figure 2 ) after filling. Nutrient levels of agricultural lands vary considerably across the region and within tracts. Producers use grid sampling to deliver nitrogen and other nutrients where it is most needed and to avoid overapplication.

Managing the Sny Island Levee Drainage District requires constant attention to interior control of runoff water, soil erosion, and internal levee maintenance, as well as monitoring external conditions and Mississippi River pressures that could lead to breaches in the levees that defend the farmland from the river. 
The extreme weather events of the last three years and expectations for increased precipitation and more frequent 10 to 15 $\mathrm{cm}$ (4 to 6 in) rain events in the future present difficult challenges to the district. Three-quarters of their $\$ 2$ million annual revenue are spent on fuel costs to run their three pumping stations continuously during periods of high water runoff.

The acreage and productive capacity of the agricultural land in the Sny Island Levee Drainage District have been maintained by the sediment-filled basins built in the 1940s and 1950s which have been reclaimed in the 1970s for crop production. It is extremely rare for such a large block of land, previously in agricultural use, to be converted to another land use, such as sediment-filled basins, for 20 or 30 years and then have it returned to agricultural use and production. The replacement settling basins built after the 1970s are at sites with diverse land uses, including stream channels, timberland, ponds, agricultural land, wetlands, and wildlife habitat. It is too soon to know what the future land use of the second set of sediment basins will be, but it is likely that some will be returned to agricultural use and production. The need for a third set of settling basins could decline as land owners in both the upland and bottomlands increase conservation practices that control soil erosion and reduce the amount of sediment and nutrients being transported into the Sny River channel and eventually pumped or allowed to free flow into the Mississippi River.

The combination of purposefully created wetlands and settling basins alongside agricultural lands protected by levees provides diverse habitats for wetland species, fishing, and recreational duck and deer hunting. The high cost per acre of land assessment pushes producers on both bottomlands and uplands to select high-value crops and to farm right to the edge of their internal drainage ditches. Fast-moving, high water in these ditches increase bank erosion where it is not held by vegetation, clogging the drainage system and increasing the need for more frequent ditching and the Sny River channel dredging. Incentives to encourage 2 to $3 \mathrm{~m}$ (7 to $10 \mathrm{ft})$ vegetative strips along-

\section{Figure 8}

Active Pigeon Creek settling basin west of Hull, Illinois.

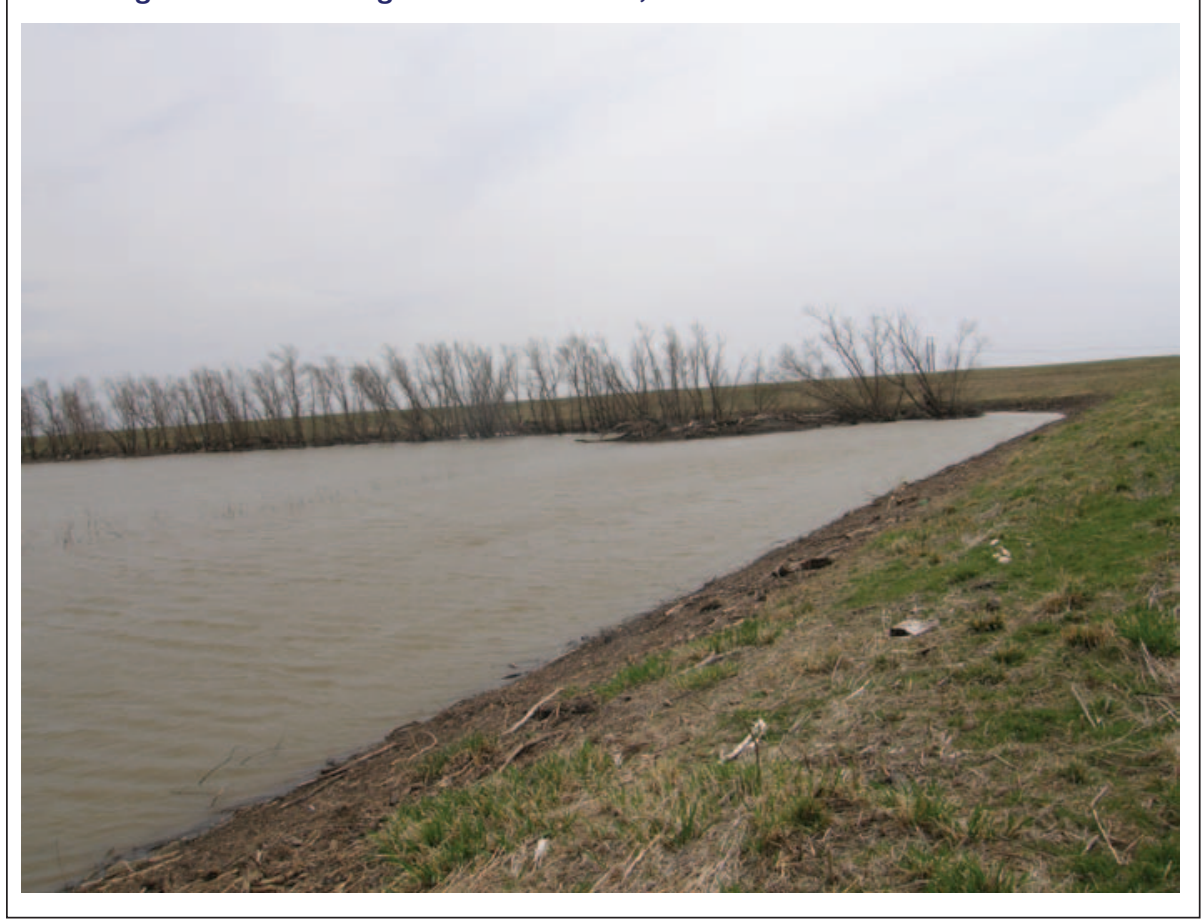

\section{Figure 9}

The Sny River watershed uplands with no-till corn planted on very steep slopes.

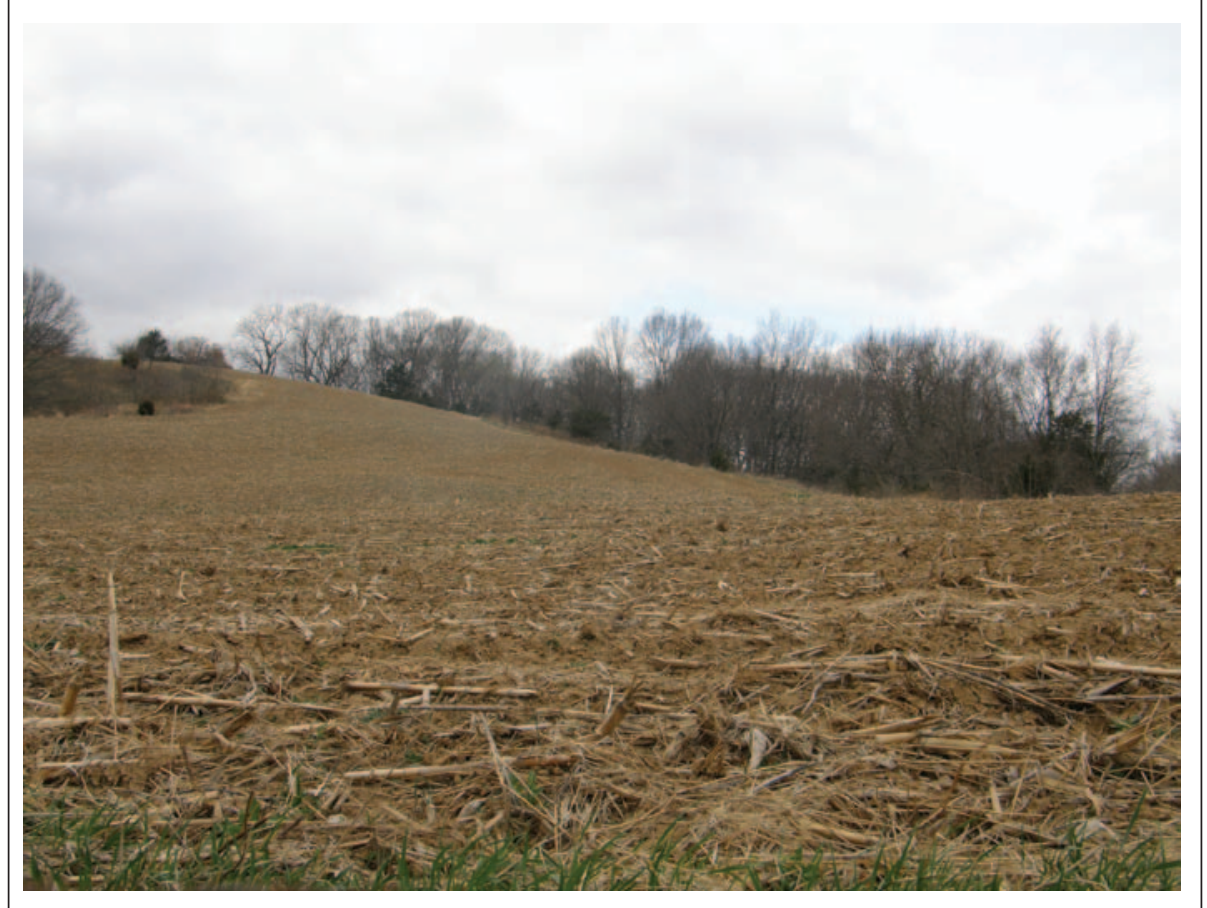

side these steep ditches are conservation measures that would hold soil in place and reduce the movement of soil from field to water. Much of the upland and bottomland farmland is already in no-till (figure 9), so producers should be encouraged to continue this practice and expand it to row crops currently not utilizing this management practice. In addition, the conversion of very steep slopes from row crops to perennial cover would help reduce further soil loss. This, however, does not address an 
underlying concern - the need for landowners to produce sufficient revenues to cover the drainage district per acre assessment to protect the region. As the price of fuel oil increases, high agricultural productivity coupled with high commodity prices will be needed. One possible way to mitigate this treadmill is to build on the diverse habitat created by this system of wetlands, sediment basins, and levees and purposefully develop an economic tourism plan to increase the recreational use of this region.

\section{REFERENCES}

Gard,W.T. 2002. The Sny Story. The Sny Island Levee Drainage District and Sny Basin. North Richland Hills, Texas: Smithfield Press.

Hopkins, C.G., J.G. Mosier, E.V. Alstine, and F.W. Garrett. 1915. Pike County Soils. Soil Report no,
11. Urbana, IL: University of Illinois, Agricultural Experiment Station.

Olson, K.R. 2009. Impacts of 2008 flooding on agricultural lands in Illinois, Missouri, and Indiana. Journal of Soil and Water Conservation 64(6):167A-171A.

Olson, K.R., and J.M. Lang. 2000. Optimum Crop Productivity Ratings for Illinois Soils. Bulletin 811. Urbana, IL: University of Illinois, College of Agricultural, Consumer and Environmental Sciences, Office of Research.

Struben, G.R., and M.E. Lilly. 1999. Soil Survey of Pike County, Illinois. Washington, DC: USDA Natural Resources Conservation Service.

USDA NASS (USDA National Agricultural Statistics Service). 2009. The Census of Agriculture. Washington, DC: USDA NASS. http://www. agcensus.usda.gov. 